\title{
Public Goods and Economy in the Early Modern Era-New Perspectives on Modern Economies and Contemporary Environmental Concerns
}

\author{
R. Bin Wong
}

This volume of essays has examined the ways in which people and their governments produced and paid for nonmarket goods in both early modern East Asia and Western Europe. We have especially considered the kinds of goods often supplied through nonmarket means at the regional and local levels of society, sometimes but not always far removed from the concerns of the central government. This perspective has allowed us to consider the early modern developments of public goods quite separately from the later crystallization of modern public finance. Early modern European public finance, as we mentioned in the introductory chapter is largely associated with the concept of the fiscal state, which is sometimes called the fiscalmilitary state because of the intimate relationship between increased government borrowing and taxation with military expenditures. The major expenditure of centralizing European states in the seventeenth and eighteenth centuries was military. State formation in Europe took place as part of the construction of relations among European states competing with one another for power and wealth. This dynamic has had profound impact of the shaping of modern politics through the expansion of European power around the world that included the early modern formation of white settler societies in the Americas, the purchase and export of African slaves to the Americas, and a trade in Asian commodities that expanded the range of products available during Europe's early modern consumer revolution. By the early nineteenth century the early modern American white settler societies had shed their colonial status to become independent countries, and by the late nineteenth century, African and Asian trading partners and their neighbors had largely succumbed to colonial rule by European powers.

Fundamental to the imposition of political authority was the presence, or at least threat, of military violence against which subject populations were largely 
unable to resist. The European deployment of military violence for a combination of political and economic aims in both nineteenth-century Africa and Asia extended political and economic logics first formulated in the early modern era and most clearly developed by the aptly titled "fiscal state." Yet the phenomena that the term most especially points out all lead to a focus on Great Britain, as Richard Bonney, one of the leading specialists on the subject, makes clear when concluding his introduction to a volume on European fiscal states: "Only one state, Britain, had reached the more advanced stage of a 'fiscal state.' . . In that sense, perhaps the book should have been entitled The Rise of a Fiscal State in Europe, c. 1200-1815, instead of The Rise of the Fiscal State in Europe, c. 12001815 " (Bonney 1999, 14). By locating the fiscal state's formation as the product of successful development of state fiscal capacities in response to military threats, Bonney locates the concept firmly within European history and provides background to Britain's rise to its hegemonic position politically and economically in the nineteenth century.

Britain's fiscal successes supplied the norm for the fiscal state. Its main early modern expenditures, especially dramatic in the rising costs of expanding its eighteenth-century navy, are part of a larger British success story of becoming the first industrial nation and Europe's most successful colonizer of peoples in other world regions. Folding the fiscal state into these larger narratives of capitalism and political power gives the fiscal state a particular prominence that is both more and less than the subject of state expenditures. It is more because the fiscal state is made part of a larger set of changes characterizing European economic and political changes. It is less than state expenditures generally because as the fiscal-military state concept in particular makes clear, it highlights one kind of expenditure, namely, those for military matters.

After the important work on the European fiscal state came subsequent efforts to make a "global" history of the fiscal state in The Rise of Fiscal States: A Global History, 1500-1914, edited by Bartolomé Yun-Casalilla and Patrick K. O’Brien. Only five of the seventeen case studies addressed non-European cases-two chapters on China and one each on Japan, India, and the Ottoman Empire. The studies in general assemble a rich trove of information on revenue strategies across Europe and the countries beyond Europe just mentioned earlier. On the expenditure side, military matters loom large in most of the European cases. The early modern European state's need to expand its revenue and become a fiscal state derived largely from the costs of its war making. The fiscal state's public finance has relatively little to do with the provision of goods and services ill suited to market mechanisms other than national defense or, what we might perhaps more accurately call in the context of early modern European war making, a successful "national offense." In his essay in The Rise of Fiscal States: A Global History, 15001914 titled "Taxation in the Habsburg Low Countries and Belgium, 1579-1914," Paul Janssens assembles data supporting his estimate that "Only one-third of the 
total local and provincial revenue from taxation was used for the government's own ends. Apart from administrative expenditure (salaries and operating costs), only public works constituted a significant item of expenditure. The government's contribution to poor relief was limited. The Church played the dominant role here, as it did in education" (Janssens 2012, 76). While others scholars in this global history of fiscal states do not make as comprehensive a summary regarding the relative size of fiscal expenditures, it is unlikely that officials in many European countries were spending much of their time or energy addressing issues of poverty and famine, infrastructure construction, or forestry management, examples of what we are calling in this volume "public goods" to stress the importance of nonmarket management and provision in all of our cases.

Our intention is hardly to argue that the "fiscal state" concept has been unhelpful to understanding the processes of European state formation. But we do suspect that the process of taking the fiscal state concept to a global scale has followed an intellectual path already well trod by economic historians of diverse dispositions who have evaluated non-European sites according to their differences from European economic practices within their preferred frames of interpretation, be these neoclassical economics, Marxist, or Weberian. One of the costs of such an intellectual strategy regarding public goods and public finance is to miss the production of goods that are in no reasonable sense private because they are not produced for exchange on the market for the mutual benefit of private parties. We have argued that such goods can be considered public goods with "public" referring to far more than only the government. Public goods are created in a social space within which market mechanisms might be present, as well as community-based exchanges and those organized by the state. They are not limited to goods and services produced and allocated by the government. Working with an expanded definition of public goods to include non-market-produced goods and services, we have been able to highlight several areas of early modern economic activity in a new way.

The payoffs from the approach we suggest are several. First, considering the provision of nonmarket goods and services addresses activities fundamental to the economic life of early modern societies that are typically not covered in discussions of the fiscal state. These include in fact activities taking place in England, the model of the fiscal state. Second, the kinds of nonmarket goods and services we discuss have clear similarities to nonmarket goods and services today for which public finance remains important. Infrastructure is perhaps the most salient example, but the provision of disaster relief also spans both publicly and privately mounted campaigns. Looking at early modern public goods and the ways in which they were financed thus offers us a different perspective on our contemporary practices from those encouraged by the fiscal state narrative.

A third benefit comes from recognizing the historical particularities of the modern industrial era through appreciation of the concerns shared by early 
modern and contemporary societies that the modern industrial era did not take as seriously. From our examination of forest management, for example, we can gain a perspective on issues of natural resource management and the environment. The industrial era was built on the exploitation of fossil fuels and their destructive impacts on climate and environment that have become more fully appreciated only in the past several decades. Resources and their exploitation were assumed to have limits in early modern societies since people had no way to anticipate the technological breakthroughs that would enable people to capture ever-greater amounts of energy and create new sources of power. Early modern management of natural resources thus bore some partial parallels with the approaches taken today when an awareness of limits is much stronger than it was between the mid-nineteenth century and mid-twentieth. Our sampling of approaches to early modern forest management can help identify examples of practices potentially relevant to the policies pondered by analysts seeking to establish some standards for best practice today. Issues of water resource management, which we have also addressed in this volume, take us to the connections between infrastructure and natural resource management because they include the use of water for infrastructural projects spanning power generation, transportation, agricultural production, and consumption.

A fourth and final payoff to highlight is more methodological than simply substantive. The subjects we cover in this volume can be found in both East Asia and Europe. Because the motivation to look for such subjects came out of intensive study of early modern Japan, we have been able to avoid the more common selection practices that follow criteria that highlight the particularities of the most successful early modern European states. The results of such familiar exercises have often told us how some countries are not like European ones without explaining directly what they in fact were like. By choosing common concerns such as infrastructural construction, natural resource management, and the clusters of activities concerning poverty policies and famine relief efforts, we are able to make comparisons in a more neutral way. In fact there is no reasonable measure of what is better or worse before we catalogue what in fact occurred across a range of cases.

At the same time, we do recognize that there are advantages to examining some case in more depth than others in order to have a sense of how public goods were created in the context of one particular country. The choice of Japan for this purpose has been made possible by the availability of rich sources and careful scholarship. The country's small size also affords the same advantages that looking at England offers. At the same time we have deliberately chosen to use as our two main cases beyond Japan a connected yet contrasting East Asian one, namely, China, and a European case, namely, Prussia, that in itself contrasts with the paradigmatic English fiscal state. This allows us in this final chapter to distinguish three spatial scales of variation-those within Europe, those within East Asia, and those variations most usefully arrayed across both East Asia and Europe. 
If we take for the moment the paradigmatic English fiscal state as a point of departure, but consider those activities that don't fall neatly under the fiscalmilitary state rubric, we can begin by considering poor relief, the one case study addressing this country that we include in this book. While there is an act of Parliament establishing the Poor Law across England, the English fiscal state had little to do with its implementation. No taxes collected by the centralizing state busy building military and fiscal bureaucracies were used to fund poor relief. No state officials were involved in administering poor relief. English poor relief depended on members of the local elites serving in the unpaid status of justice of the peace or magistrate. Resources for funding poor relief were raised and used locally. While certainly a nonmarket good, poor relief has traits of a communitybased activity organized and funded by local people for the benefit of locals, at the same time it can be considered an activity promoted by the state. To the extent that it was a state activity, it alerts us to the limitations of the fiscal state concept for addressing public finance issues. But the notion we employ in this volume of public goods as nonmarket goods allows English poor relief to be a public good because our formulation explicitly includes the varied acts of elites to provide goods and services by nonmarket means that create value for others and typically with some kind of social benefits that are positive externalities to the individual benefits derived from market transactions. While the presence of nonmilitary expenditures at more local levels that are missing from the main message of the fiscal-military state concept has already been noted by others (e.g., Innes 2009), locating such efforts in a public goods frame of reference has not been, to our knowledge, done.

If we turn to another of our three subject areas, English practices for infrastructure building are distinctive. Where water control projects in both China and Japan, as well as Prussia, were undertaken by different constellations of actors and market mechanisms played little to no role, the development of the English rivers was similar to the development of roads. For both, private investments played a crucial role in the increased funding of transportation networks in the seventeenth and eighteenth centuries. Dan Bogart has shown that turnpike trusts could cover costs by charging tolls and accessing needed capital by mortgaging future toll receipts (Bogart 2005, 2011). From a related but distinct perspective, Piet de Vries has suggested that English canal projects were joint ventures, that is, public-private partnerships combining the efforts of government and private entrepreneurs (de Vries 2013, 15). These institutional innovations are part of the broader financial market innovations that spanned both public and private finance in eighteenth-century Britain. Another institutionally distinctive political feature was the opportunities for competing interests to express their concerns and desires regarding river navigation improvements in Parliament, where a series of Inland Navigation Acts enabled private actors to pursue projects they anticipated would yield profits (Yamamoto 2018, 143-156). 
Infrastructural public goods for transport in East Asia and Prussia were handled differently in England. Among the East Asian and European cases, public goods creation along rivers was also pursued to improve and protect agricultural interests as well. The relative dependence on river control projects for agricultural production was higher in East Asia than in our European cases because the irrigation needed for paddy rice cultivation presented a need for which there was no near equivalent in Europe. East Asian households engaged in small-holder agriculture were unable to mobilize the resources or mount the organizational efforts themselves to assure the scales of spatial coordination needed to manage water control operations, the spatial scale of these projects being far greater in many Chinese cases than in Japanese ones. Returning to the Prussian case of transportation infrastructure, Sascha Bütow's chapter on road construction in fifteenth- and sixteenth-century Brandenburg explains how important municipal initiatives were to creating a network of roads that connected cities to one another and along which commercial traffic could develop. The status of German cities and their finances were embedded in the relations that cities had to other territorial authorities, including princes and the Holy Roman Empire. The activities Bütow recounts emerged from a thirteenthcentury foundation of urban public finances being independent from and more developed than those of territorial noble rulers (Ormrod and Barta 1995, 74-75, Hocquet 1995, 91-92).

We see German territorial rulers taking on a larger role in subsequent centuries regarding infrastructure, as Heinrich Kaak shows in his detailed case study; while he certainly notes that there was a longer tradition across Europe more generally of organizing river dikes to reclaim agricultural land and protect land already being cultivated, the financial and organizational scales of dike projects in Kaak's Prussian example demonstrate just how large the capacities and commitments to infrastructure were that a major German ruler could mount in the eighteenth century. Under Frederick I (r. 1701-1713) and Frederick II (r. 1740-1786), Prussia became a leading European power and the core of what would be the future unifying drive for Germany in 1871. Kaak's Prussian case study combines local dike associations and the king's major projects into a single framework of riverine infrastructure. While regional in scope the organization of riverine infrastructure spanned local and central government actors in ways that fit Elinor Ostrom's concept of a "nested hierarchy" of actors taking on components of managing a common pool resource, much as Chinese water control projects reflected this attribute, often on yet larger territorial scales.

In Britain, the fiscal state was not much involved in either poor relief or creating the transportation infrastructure of roads and navigable rivers, beyond passing legislation to mandate local efforts at mounting poor relief and to encourage private investment in infrastructural improvements. Government involvement in financing and organizing poverty policies and infrastructure projects occurred in 
both China and Prussia and involved activities not conventionally considered to be part of the fiscal state's activities.

Moving on to consider English material related to our third subject of forests, early modern England had both public and private forestlands. The public lands were those forests claimed by William the Conqueror (r. 1066-1087) who brought with him from Normandy forest law and forest courts, which were then used to define the Crown's control over almost one-third of the kingdom's land. Initially the Crown's principal interest in forests, which included fields, pasture, and villages as well as forests proper, was the use of the forests themselves as hunting preserves. Rulers recognized their royal forests to be subject to multiple uses and granted licenses for use of the forest lands. In the early modern era, the expanding Royal Navy's need for timber meant that the royal forests joined private estates, the colonies, and the Baltic region as sources for naval timber (Scott 2008, 339-347). Private forestland in England was controlled by lords who held title over specific woods but shared with their manorial tenants the use of other woods. These common woods were managed according to custom, which included the commoners' rights to access resources and use them for specific purposes. Different categories of people enjoyed different rights to timber and wood for house building and repair and for firewood (Scott 2008, 448-498). The multiple uses of forestlands in early modern England suggest the accommodation of diverse claims that cannot be reduced to simple public-private binary. This general observation is in line with what the Japanese, Prussian, and Chinese chapters of the volume also suggest regarding the presence of various ideas about the commons that were variously accommodated alongside other claims or challenged by alternative demands. The multiple claims placed by different people on a lord or ruler's forestlands or, in the Chinese case, lands simply labeled "public" (公) suggest more similar and complex ranges of challenges in defining the commons and the relation of the commons to other claims on forestland.

In Takashi Iida's Prussian case the king used his forests as the source of timber for ship building in foreign countries. This revenue-making operation encouraged Frederick II to begin afforestation projects to sustain the timber supply from which he derived profits. The Prussian rulers also had to negotiate the access of their subjects to these forests for both timber and firewood. Nineteenth-century Prussian rulers moved to end the access of their subjects to timber and firewood in order to sell more of the former and make the latter available at lower prices to people clearly poorer than those who had previously exercised claims on firewood gathered in forests. The evolution of claim making on forests used by the ruler for market-based commercial operations and by his subjects as public goods differed in Prussia and Japan. Takeshi Aoki shows that the late-nineteenth-century Meiji government recognized the Tokugawa-era peasant claims to forestland nominally held by lords because peasants in some areas provided the upkeep of the forests through replanting. This Japanese practice of peasant-based afforestation contrasts 
both with the Prussian case of tree planting under the ruler and with the practice to be considered later of commercial afforestation in some Chinese forests that supplied a long-distance timber trade.

Yoshiyuki Aihara's chapter on Qing forests as commons considers the situation in a variety of forestland legal cases, especially from three provinces south of the Yangtze River, where he finds examples of the tragedy of the commons because forests were depleted without replanting. Not surprisingly, given the Qing empire's large size, there were other forest management regimes in other parts of the empire. In the northeast, the Manchus retained forests on which lived a variety of indigenous groups who supplied the court with different forest animal pelts and other forest products as tribute (Bello 2015, 63-115). The Manchus also established more than a hundred hunting reserves, which featured large amounts of forestland. The Mulan Weichang in what is today northeast Hebei province near the city of Chengde was the largest reserve and site of the annual autumn hunt begun in the 168 os and continuing until 1820 (Menzies 1994, 55-64). Other forests in China produced timber for commercial sale, a practice of considerable importance already by the twelfth century (Miller 2015, 234-283). During the early modern era the demand for timber in China's most economically developed region of Jiangnan, an area centered on modern-day Shanghai after the mid-nineteenth century, stimulated the development of commercial trade from the southwest province of Guizhou more than one thousand kilometers away. The financing of afforestation was met by selling forest land as shares for which a secondary market existed to facilitate the circulation of capital over the two to three decades required for the timber-yielding trees to mature (Zhang 2017).

The subject of poverty and famine shows variations within both East Asia and Europe regarding the roles and relative importance of different social and political actors. For infrastructure, the English case seems quite different from both the Prussian and the East Asian ones; the main difference between Prussia and East Asian cases was the more prominent role of water control issues for agricultural production in Asia. Finally, for forestry management we can see diversity of forest use and management within each case study as well as among them. It makes clear that the different dimensions of comparison help us to distinguish among types of comparisons worth noting and the challenges of combining different types of contrasts into more general evaluations of similarities and differences found in public goods provision in the early modern era.

Establishing the levels and dimensions of generality that come out of using English, Western European, or Euro-American metrics of evaluation can be advanced through adopting a non-Western case as the reference point for evaluating several others. In this volume we have chosen early modern Japan. Japan enjoys features that make it similar to European countries-especially the spatial and demographic scales of the country and other features that make it related to China-in particular overlapping sets of values and some similar forms of 
agricultural production. We can therefore observe different sets of similarities and differences that early modern Japan has with its Chinese neighbor and with European countries that are more similar to Japan in size and some features of political organization.

To recap our use of early modern Japan, as a reference point: Variations within East Asia begin from a shared cultural base. The Japanese and Chinese share some Buddhist, as well as Confucian, beliefs and practices, which include certain views regarding nature and the aspirations of people to live in some sort of basic harmony with that natural world. They also faced similar challenges in organizing paddy rice cultivation, which meant coordination of water use among groups of agricultural households depending on a common source of water who organized access in ways that could be deemed fair and effective. In both spiritual and material realms therefore, Japanese and Chinese shared sensibilities and challenges that were distinct from those found within early modern Europe. Yet, the ways in which Japanese and Chinese actually organized water control varied considerably. At very local levels, groups or networks of households reached agreements regarding how to manage access to water for irrigating their fields. In both societies there was also the need to mount larger water control operations that required local leaders to mobilize resources and labor to repair dikes and dredge river channels. The differences in geographical and demographic size of the two countries meant that there were far more local water control groups in China that were in turn linked to other similar groups than was the case in Japan. More specifically, Japan has a large number of relatively short rivers flowing down mountains so that the technological and organizational challenges of water management differ from those in China.

In Japan the marked expansion of water control projects depended on new kinds of mobilization taking place beneath the domain level of government. The provision of some public goods in early modern Japan depended greatly on nonstate actors. In China officials and local elites played related but often distinct roles, with officials becoming involved in larger projects that required some kind of special financing and plans for mobilizing labor to implement the work needed. A combination of official and local elite activism to maintain, repair, and even expand water control projects characterized eighteenth-century Chinese nonmarket provision of collective or public goods. The increased efforts at a particular local level of Japanese society contrast with the increased activism exhibited by Chinese officials at multiple levels, often responding to calls from the court or from provincial-level leaders. In both countries the historical evidence suggests an increase in public goods of the kinds we have examined being produced during the early modern era, especially during the eighteenth century. But the constellation of mechanisms deployed to achieve these increases was certainly different.

Innocent of the facts, there is little reason to expect the differences in mechanisms for public good provision in Japan and China to involve greater bureaucratic 
involvement in China and less in Japan since Japan is a far smaller area to govern and thus far more amenable to centralized bureaucratic control than an empire the size of eighteenth-century China. The actual contrast of greater bureaucratic involvement in public good provision in China than in Japan must however be qualified since the viability of Chinese public goods provision depended crucially on the efforts of local elites whose embrace of a neo-Confucian social agenda, the formulation of which began in the twelfth century, made elite efforts largely complementary to those of officials. The limits to bureaucratic reach and penetration below the county level were substantial in eighteenth-century China, but the impact of the bureaucracy's agenda cannot be measured solely by the formal bureaucracy's extension into local societies since local elites were in many ways responsive to the priorities that officials were setting (Wong 1997, 105-126). The relevant temporal frame within which to situate Chinese and Japanese public goods provision also differs since the early modern Chinese practices are part of a centuries-old set of policy strategies themselves developing out of political principles and practices articulated and elaborated beginning in the centuries before imperial unification in the third century вСE.

The temporal and spatial differences between the Chinese and Japanese cases lead us to consider the temporal and spatial similarities that Japan shares with European countries. The founding of the Tokugawa shogunate in 1603 and its successful ending to an era of military competition within Japan and the development of its capacities to rule successfully for more than two and a half centuries make it a state comparable to those European states that also embarked on processes of consolidating rule over previously fragmented territories and established themselves as effective states. The tendency to make these comparisons follows from a larger recognition that in the late nineteenth century and early twentieth Japan proved to be the only non-Western country to have begun processes of industrialization and militarization that made it comparable to and ultimately a competitor with European countries and the United States. Historians of Japan developed desires to establish a longer period of transition from the early modern era to the modern era to parallel that seen in European history, an important part of a larger process of making Japanese history more familiar and thus credible to Western sensibilities. There are indeed parallels and similarities worth noting, whether we wish to focus on economic developments like rural industry or proto-industry, social changes including urbanization, or political transformations such as the formation of stronger governments. In all these respects Tokugawa Japan's similarities to Europe can be clearly seen. Considering the ways in which public goods provision was formulated and the very specific ways in which Japanese public goods provision considered in this book was significant for economic infrastructure, common people's material welfare, and popular access to natural resources helps us see ways in which Japan was also different from Europe in some significant ways. 
Before considering Japan-Europe comparisons among the major topics of this volume, we should recall how Tokugawa Japan does not fit very well the model of a European fiscal-military state since the central government was not pursuing an agenda of war making. Military expenditures would only become increasingly important in the late nineteenth century and the first half of the twentieth, as the Meiji state transformed Japan into a challenger to Chinese hegemony in East Asia and then in the first four and a half decades of the twentieth century subsequent Japanese governments made the country into an imperial power seeking political and economic dominance over Northeast and Southeast Asia as well as China. During the early modern era of the Tokugawa, however, the state did not pursue a European fiscal state kind of agenda. The crucial level at which new kinds of initiative emerged in early modern Japan, especially from the late eighteenth century forward, to expand public goods provision was both at the village level and at a level above the village, which lacked any administrative identity and which was led by elites who were not employed by either the shogun or any of the families leading the various domains. In part such actions were compensatory for the reduced capacities of government. These new activities were welcomed by the political authorities in charge of different domains who saw them as promoting the economic potential and security of their subjects.

Comparing the Prussian cases (Prussia defined to include those territories under eighteenth-century Prussian kings) with Japanese cases suggests that rulers and government officials played more prominent roles there than in Japan. These contrasts follow in part from the different kinds of political authority enjoyed by Prussian municipalities and by Prussian nobilities enmeshed in a feudal system's social relations. What the Prussian and Japanese cases share is the creation of public goods well below the spatial scale of what would be the late-nineteenth-century states of Germany and Japan. Both the Japanese and Germans states of the late nineteenth century grew and became military powers as their industrial economies expanded to support their larger territorial aspirations. But those developments are more parallel to the fiscal-military state narrative that highlights early modern and modern British successes at war making than the early modern German and Japanese public goods provision addressing poverty, economic infrastructure, and forest management covered in this volume.

If we turn to issues of water management in contemporary Germany, we discover that the German water supply issues are actually parts of a far larger European Union policy arena that takes on a spatial scale of issues more akin to those faced in China or the United States for water management matters. Germany-Japan contrasts seem irrelevant. The message of these different temporal snapshots of early modern, modern, and contemporary situations alerts us to the ways in which similarities and differences among the public finance concerns within a country can change in both related and distinct ways. What makes each country's particular history potentially relevant has already been raised by 
Masayuki Tanimoto in the opening chapter, where he suggests that early modern local and regional public finance practices can influence subsequent patterns of activity in modern times, as the persistence of early modern expectations of claims made on Meiji-era state forestry policies suggests. This case demonstrates how the definition of what become legitimate claims early in the Meiji era was negotiated on the basis of older understandings-acceptance of a new public finance regime depended in this case on people believing that regime would likely carry forward some version of older practices. This case poses a perspective on the move from early modern to modern quite different than those posed by theories based on Western experiences that predict forward historical movements in regions beyond Europe and North America simply to follow their lead on the fiscal-military state model.

Returning to the incompleteness of the early modern fiscal-military state model for tracking changes in all the public goods relevant to economic success in a broader Eurasian context, the afterword chapter by Patrick K. O'Brien in a volume on the global history of fiscal states sets up the significance of the state's fiscal capacities for taking advantage of trade and developing human capital and new knowledge. "In the prevailing medieval and early modern international order of geopolitical violence, conquest, imperialism, and mercantilism, as well as weakly enforced laws and rules for the protection of production and exchange located within and beyond the frontiers of empires, realms and republics, marked by divided sovereignties, the formation of well and consistently funded centralized states remains (in the view of most historians who study these centuries) something approximating to prerequisites for securing greater gains from trade and from domestic and foreign investment in the accumulation of physical and human capital and for the production and diffusion of useful and reliable knowledge" (O'Brien 2012, 444). Defining the early modern international order by "geopolitical violence, conquest, imperialism, and mercantilism" certainly captures conditions within the European world region and Europe's relations to several other world regions. But it hardly applies globally—China alone had a larger population than that of Europe and politically was only marginally involved in the geopolitical violence initiated by Europeans. Significantly, they rebuffed early modern European military advances, achieving what Tonio Andrade has recently called military parity (Andrade 2016). The Chinese thus were able to exercise a far larger role in determining the conditions under which eighteenth-century trade with Europeans took place than people in other parts of early modern Asia or than they themselves would enjoy after British iron ships arrived in China in the late 183os. They benefited from trade despite not having the kind of fiscal state exemplified by the British case. How important fiscal capacities actually were for influencing investment into human capital or for producing and disseminating new knowledge is difficult to pin down and O'Brien offers little concrete evidence of causal connections. 
If we consider eighteenth-century China as a world region comparable to Europe in spatial and demographic terms and consider its domestic relations (same spatial scale as relations among European polities) and its foreign relations with countries of Central, Northeast, and Southeast Asia, we see no mercantilism and relatively little violence. Only with some groups in Central/Inner Asia did Qing dynasty military activity play a long-lasting role more similar to the even longer-lasting persistence of military violence in Europe's conquest and imperialism of Africa, the Americas, and Asia. O'Brien lifts the fiscal state from its original connection with the military to make the fiscal state key to the development of modern economies and modern state policies to support industrial economies. "State formation was part and parcel of the process of long-run growth and could well be an important chapter in narratives designed to explain divergence between Eastern and Western economies, and possibly a key factor behind the observed sequence of leaders, followers, and convergence in any global history of modern industrialization" (O’Brien 2012, 444). Interested principally in explaining economic change, his interest in the fiscal state leads us to see what he calls the "formation of economically effective Eurasian states," with the criteria of effectiveness relating to economic growth rather than criteria anchored more narrowly and deeply in public finance and the ways in which public finance changed in different parts of the world between the early modern and modern eras.

O'Brien's interpretation of the fiscal state is one of several ways the term has been understood. Philip Harling and Peter Mandler, for instance, see a clear change from a fiscal-military state to a laissez-faire state in Britain between 1760 and 1850. They remark, "It was primarily the need to wage war on an unprecedented scale that fueled government growth up to the late 1810s" (Harling and Mandler 1993, 47). They further note that government expenditures declined after the defeat of Napoleon in 1815: "In the immediate postwar period, there was consequently a considerable deflation of government expenditure in absolute terms, reaching its nadir in 1834; relative to the population, spending shrank rapidly" (Harling and Mandler 1993, 60). While there was a contraction of central government expenditures, the development of nineteenth-century British public finance supplies a striking contrast to both the early modern fiscal state's expansion driven by military expenditures and Patrick K. O'Brien's reformulation as a state fostering modern economic growth. According to Martin Daunton, “The fiscal system should therefore be located in the context of voluntarism and the strength of civil society, the role of municipal culture, and the relative autonomy of professional bodies. The English fiscal system combined a diffuse pattern of delegation or subsidiarity in the collection and administration of the tax, with an attempt to preserve generalized legislation that removed discretionary power from the authorities" (Daunton 2010, 50). Daunton's characterization reminds us much more of eighteenth-century poor relief practices than it does of the fiscal-military state and O'Brien's focus on state support for economic growth. This contrast between fiscal 
capacities to affect economic growth and government expenditures to serve social purposes in turn represents two competing priorities of public finance present over the course of the twentieth century and still with us today.

If we return to the eighteenth-century Britain of John Brewer's "sinews of power," a phrase that captured the close connections between warfare and taxation, we can recall that the fiscal-military state became the robust actor nourished by revenues created by the East India Company's commercial capitalists accessing the Asian commodities and that the state developed the military muscle to assert its political will within Europe and beyond. But Brewer also noted that this state in fact shifted from its earlier domestic concerns to place priority upon central state relations with people and places abroad. As Joanna Innes's research suggests, prime targets of eighteenth-century domestic expenditures became social issues spawned by those new priorities, even as the familiar concerns of dearth, disease, poverty, and crime continued to haunt government leaders. These older issues were now linked to the social problems caused by war making, in particular the domestic transition challenges of military demobilization after the conclusion of a war, when crime rose and the ranks of the vagrants and poor swelled. Innes shows that central government funding to meet such problems was in fact far more limited than local efforts to mobilize resources, but suggests the symbolic significance of central state interventions when and where they occurred (Innes 2009). Thus, social expenditures in eighteenth-century Britain were themselves responses to some of the consequences of increased military expenditures preceding them.

The diminished nineteenth-century focus on war making removed the military origins of domestic social expenditures, and, as Harling and Mandler's research indicates, expenditures overall declined through 1850 . As we move through the nineteenth century, several studies of other countries in Europe stress the expansion of state expenditures for social projects, such as education, rather than for promoting economic growth (Cardoso and Lains, 2010). Taking capital away from investment in production is often seen to reduce economic growth. At the same time, however, social spending on education can help create human capital, which in turn contributes to making higher levels of labor productivity possible. Peter Lindert has demonstrated that the growth of nineteenth-century government social spending, a process he calls "growing public," does not appear to have had adverse effects on relative rates of economic growth (Lindert 2004). His work suggests that social expenditures could therefore at worst not derail economic growth, and indeed, could even be considered to create as a perhaps unintended consequence improvements in human capital that O'Brien counts as part of what his fiscal state pursues to support economic growth.

Our presentation of materials on early modern provision of public goods other than military ones identifies forms of spending that also have mattered in the modern era. From a perspective based on Japanese history, one could say that the reduction of military spending in at least some countries of Europe in 
the early nineteenth century created conditions in which public goods creation sometimes took place at more local levels, as had been the case in early modern Japan. Central governments became more involved in social spending by the late nineteenth century in both European countries and Japan; in a sense they converged temporally along a similar path, but not simply through the Japanese emulation of Western practices, as is conventionally claimed. Nor, to be sure, were Europeans copying Japanese practices. Rather, both European and Japanese states were attending to some increasingly similar economic, political, and social challenges even as they also faced distinct economic opportunities, addressed different social relations and expectations, and made varied political choices. The chapters of this book supply a new and different vantage point from which to assess public goods provision and public finance beginning from practices of the early modern era beyond those highlighted by the fiscal state.

Looking at early modern examples of public goods creation in both East Asian and Western European settings has led us to identify ways in which a range of actors, especially at the local level, and both within and beyond formal government, created some of the public goods either essential to early modern economic activities or conceived as interventions compensating for the limitations of economic production and distribution. Since we consider public goods as simply nonmarket-produced goods depending on more than just some immediate personal connections between producer and consumer, we can see how government and nongovernment actors created goods that mattered to early modern economiesthe creation of economic infrastructure, the management of natural resources, and the capacities to address poverty. Some final remarks on each follow.

For infrastructure, the importance of community groups is especially salient in our Japanese case study by Jun'ichi Kanzaka on Japanese civil engineering projects between the seventeenth and nineteenth centuries. In his case study, the overwhelming purpose of water control projects was to expand paddy agriculture and thus improve people's material welfare and assure their capacities to pay the high levels of taxation imposed by domain and shogun authorities. Households within village communities pursued their shared interest in developing water control investments with the support of their local governments. Kanzaka also notes how villages disagreed with one another over water use, illustrating the kinds of issues that Elinor Ostrom highlights in her analysis of common pool resources and in particular her concept of nested hierarchy of relations responsible for creating durable management of common pool resources.

Our Chinese case study, which, being in the capital region, may especially include state efforts, demonstrates a larger scale of bureaucratic organization and greater range of intended goals from infrastructure investment, including environmental protection, riverine commercial transport, agricultural productivity, and work relief for famine victims. In addition, the author Takehiko To also makes clear the temporal dimensions of the central government's effectiveness 
in promoting infrastructure expansion and maintenance; eighteenth-century successes could not be continued in the nineteenth century for environmental, economic, and political reasons. The specific array of priorities for infrastructure expressed in the capital region were certainly reflected more generally across the eighteenth-century empire, but the practicalities of raising capital and marshaling labor were not left in the hands of officials but also included both local elites and community groups, as the chapter on Chinese approaches to poverty and famine relief outlined. In both China and Japan such infrastructure activities involved community groups, elites, and government officials. In Chinese cases especially, official involvement occurred from the center, through the province, and down to the county. It is difficult to discern any sharp division between public and private goods in the conventional economic sense of the categories because both are present and, between them, we find the crucial role of organizing common pool resources. We have opted for expanding the "public" category to include a variety of nonmarket approaches that span being community based, elite led, and state managed. Such a taxonomy makes clearer the alternatives or complements to market-based activities. The same conclusion can be drawn from forest management, where we observe another set of ways that the conventional taxonomy of public and private goods can be usefully revised to include those goods usually not included in either.

In the contemporary world, we can distinguish between three ideal approaches to forestry management based on state control, entrepreneurial exploitation, and community-based decision making. In reality the three ideal logics are entwined in multiple ways-in some countries, like Nepal, governments have promoted community regulation of forest land, while in larger countries with forests subject to multiple objectives a far more complex set of policy practices has emerged over time, as can be observed in American government approaches to public and private forestlands in the Pacific Northwest (Edmonds 2002, Cashore and Howlett 2007). Turning to our German and Japanese case studies one last time, we see in the transitions from early modern times to policies of the late nineteenth century that German people's access to forestlands became increasingly limited even if not completely terminated at the same time as Japanese villagers' claims to forestland use were affirmed. When we add Yoshiyuki Aihara's study of Chinese forestland commons, we learn that a state's capacity to defend the commons could be limited, in the Chinese case by the scale of the empire. Aihara suggests that the subsequent twentieth-century evolution of policies toward forestlands as commons remained unresolved. Together these cases make an argument for recognizing that twentieth-century changes in forestland management could only be varied and complex, well beyond the simple contrast for the use of commons promoted by the paradigmatic English case of enclosures.

The kinds of forestland policies pursued in this book's case studies also form a modest counterpoint to one of the prominent themes in early modern global 
history as it has taken an environmental turn. The environmental historians' views of natural resource depletion in the early modern era in some ways echo our contemporary concerns. Arguments about and evidence of deforestation in China, Japan, and England point to resource constraints in the early modern world that make their situations more similar to our own than might otherwise seem plausible. At the same time, we have seen different early modern efforts to navigate the issues posed by forestland management that we might consider as we evaluate the diverse challenges and complexities confronted by policy makers today. In particular we have mentioned Japanese evidence of peasant afforestation and some Chinese and Prussian practices of tree planting to assure the maintenance of sources for the eighteenth-century commercial timber trade, alongside other policies demonstrating competition among alternative uses of forestlands and their products with resulting strains on the maintenance of forestlands in some cases.

A similar takeaway regarding the potential usefulness of considering earlymodern-era practices for pondering contemporary challenges comes from looking one last time at issues of poverty and famine. Mitsuo Kinoshita stresses in his chapter the importance of micropolitics to understanding the particulars of addressing the issues of poverty and famine and the reasons for variation within a single country. To this observation we can add that variations among early modern countries can be associated with the distinct sets of political ideologies and institutions each had. Differences in political ideologies help account for the relative priority that governments assigned to addressing poverty and enacting famine relief. Nobel Prize laureate Amartya Sen famously has argued that famines are not simply caused by supply shortfalls but in fact can occur when there is food available-famine in such situations therefore results from the absence of entitlements that the poorest strata of society can claim on existing food supplies. He further suggests that the failure to recognize the entitlement of the poorest people to food is less likely in a democratic political system where a free press will expose state failures to protect subsistence (Sen 1981). Sen's argument highlights the linkage between a free press and unacceptability to people in general of living in society where the poor are starving. This truth works to explain popular expectations and state policies in democracies after World War II, but doesn't help us grapple with contrasts in poverty famine relief policies in early modern times.

Our Japanese, German, and English cases all point to the crucial roles of local actors, in the English case guided by directives coming from the central government and in the German case from a smaller-scale territorial state. The Chinese case in contrast highlights the existence of both a political ideology and state institutions that framed and motivated activity to address poverty and famine on more than local scales. While the chapter on China doesn't include any analysis of the micropolitics that Kinoshita uses to suggest the reason for contrasts among other case studies, it is certainly plausible to posit the importance of micropolitics within China as well. Certainly, the changes in central state capacities and 
proclivities to sustain infrastructure that Takehiko To observes based on his analysis of capital region water control fit with what Kenneth Pomeranz finds for the part of inland North China he studied and what Pierre-Etienne Will and I found for China's granary system (Pomeranz 1993, Will and Wong 1991). In all these cases the nineteenth-century diminishing of state capacities combined with a shift in central state priorities necessarily made the provision of public goods far more dependent on more local levels of decision making. That would of course change dramatically after 1949 when the party-state centralized and expanded state capacities but would also fail tragically to manage the famines resulting from the disasters of the Great Leap Forward (1958-1960).

Readers who have worked their way through all the individual chapters of this volume may well have some uncertainty about how to combine essays that treat different centuries, centered to be sure on the early modern era, but also reaching back into the late medieval and stretching into the modern era. There is of course a virtue in being able to place an early modern set of practices in a deeper historical perspective, as I tried to do earlier in this chapter regarding the two German case studies of part 3. Placing those two cases from the fifteenth and sixteenth century and eighteenth century in an even longer temporal frame allows us to reconstruct what many scholars have argued that early-modern-era political successes displayed, namely, the centralization of political power and the construction of larger bureaucratic capacities. This is a major theme in Victor Lieberman's critically acclaimed Strange Parallels: Southeast Asia in Global Context, c. 800-1830 (Lieberman 2003, 2009). Brandenberg-Prussia is not one of Lieberman's case studies because he only considers histories of polities that exist in the world today. But the building of the early modern Prussian state meets the criteria of "strange parallels" through the end of Lieberman's period of coverage, circa 1830, but Prussia doesn't become a twentieth-century state. In other words, parallels at one moment of history don't predict continued similarities at a later date; only Lieberman's case selection guaranteed that outcome. At the same time we can note that early modern public goods practices in Prussia likely helped prepare this polity to take a leading role in constructing the modern German national state, a complex amalgam initially comprising twenty-five formerly autonomous states.

By broadening our conception of public finance from that used in contemporary times and for which a stark divide exists ideologically and institutionally from private finance, we offer a view of early modern practices addressing poverty and dearth, economic infrastructure, and natural resource management that embraces the efforts of political actors to act as economic agents by influencing the productive capacities of their economies and to address the limitations of their economies to provide adequately for all the people all of the time. These activities do not figure very visibly in our understanding of how public finance worked in the early modern era or in our more general understanding of the significance of public finance to the twin processes of modern state formation and economic development. 
Regarding politics, the reasons relate to our persistent preoccupation with narratives of the fiscal-military state basic to the larger themes of modern state formation and from which concerns about economic development have spawned related ideas about the importance of public finance to economic development.

By looking at other ways early modern public finance mattered to economic life, we have built on the insights of scholars who have considered the ways in which the Japanese economy was supported by policies pursued in domains outside the control of the shogun's government. Such a vantage point encourages us to look at types of public finance that did not concern the competitive concerns of early modern European rulers. In the first instance we can conclude that there were in fact other important targets of public finance that affected economic possibilities and prosperity in early modern times. These targets, including poverty and dearth, economic infrastructure, and natural resource management, certainly have been studied by specialists for quite some time, but their research fails to fit comfortably within more general narratives of historical change.

This volume has focused on the early modern era to view ways in which governments and elites addressed subjects they deemed important to their economic prosperity and the material well-being of their poorer neighbors in two parts of East Asia and two parts of Europe. Each of these places became important sites of economic development at some point between the late eighteenth-century onset of industrialization and the present day. We have considered the ways in which government agents, especially those below the level of a central state according to the norms crystalized in the nineteenth century, often played crucial roles in creating public goods important to the growth potential of their respective societies and to addressing the problems of poverty and dangers of dearth. Our findings are no substitute for but rather a complement to the more common concern expressed for what centralizing early modern European states did to increase their fiscal capacities in order to garner resources to build military strength.

Even as multiple paths from early-modern-era public goods provision to modern-era public finance become more visible from the kinds of topics covered in this volume, we also recognize that what had been a largely European interstate geopolitical competition in early modern times was transformed by the late nineteenth century into a form of competition found in other world regions as well. Thus, Japan's geopolitical rise in East Asia entailed its state undertaking military mobilizations akin to those of an earlier century in Europe. These in turn depended on the state extracting more revenue and devoting more effort toward expanding the country's war-making potential. What differed between Japan's rise in East Asia compared to Britain's rise within Europe beginning some two centuries earlier was the kind of economy providing the state its much needed resources-eighteenth-century British economic success was founded upon its commercial capitalism and late-nineteenth-century Japan was building the world's first non-Western industrial capitalist economy. Those industrial capacities also 
mattered to Germany's geopolitical rise following its relatively late formation, within a European context, as a national state. Germany's pursuit of geopolitical gain was premised on its expanding industrial might affirmed by its becoming Europe's largest economy by the turn of the twentieth century. Germany was thus able to pursue geopolitical competition within Europe that had evolved out of a pattern present in Europe in early modern times, much as Japan was able to extend what had been a more specifically European geopolitical process to East Asia in the late nineteenth and early twentieth centuries.

At the other end of the modern era, our present moment in contemporary history, the modern-era priority on economic growth as the focus for understanding economic development and dynamics has required some reframing as we increasingly acknowledge limitations to continued economic growth and recognize the intimate relations between economy and environment. We have become more aware since the late twentieth century about issues that were early-modern-era concerns regarding poverty and dearth, economic infrastructure, and natural resource management. The issues of poverty and vulnerability to food shortages affect not only people living in areas lacking access to modern technologies and the abilities to improve agriculture or develop industries, but also people in well-developed societies where gaps between rich and poor have been growing in some places for much of the past several decades. Neither markets nor states, whether separately or together, seem adequate to meet the present-day challenges of conceiving food availability in ways that increase access to those in need of sustenance, thus making the examples of how related issues were confronted in other times and places possibly relevant to our construction of policy alternatives.

Another weakness of markets and states concerns the maintenance of economic infrastructure in mature economies and the inabilities to expand infrastructure where economies lack such facilities. The popularity of the concept of "public private partnerships" to characterize a mix of government and private sector efforts to fund and manage large-scale infrastructure projects points to contemporary realities more in line with early-modern-era practices than those of the modern era when states had been able to fund and manage public goods and services that included infrastructure. Finally, among our three topic areas, forest management today involves a public goods aspect that extends the range of issues understood in the early modern era due to the role that large forests can play in carbon capture, a process crucial to environmental sustainability threatened by forest destruction, the economic value of which for conversion of land into commercially productive prosperity motivates deforestation. ${ }^{1}$ Responses to the negative environmental implications of deforestation are of course part of a contemporary awareness of the dangers posed by climate change, yet they also represent an awareness of the different groups of people who benefit from forests as a public good that transcends the dichotomy of public and private enshrined in the state/market binary. 
We hope this volume has persuaded the patient reader who has taken in the pictures of Japanese, Chinese, Prussian, and (for one of our cases) British scenes of early-modern-era public goods provision addressing poverty and dearth, economic infrastructure, and forestry management to recognize important traits of public goods and public finance that help explain why that era was both connected to and different from the modern era covering the nineteenth and twentieth centuries, and yet resembles in other ways the world through which we make our way today.

\section{NOTES}

1. To compensate for the economic value of destroying forests, a multilevel effort reducing emissions from deforestation and forest degradation in developing countries (REDD+) was launched in 2008 by the United Nations. Among the contributors is the Norwegian government, which has made major investments to reduce greenhouse gas emissions caused by deforestation and forest degradation. The effort is under the Ministry of Climate and Environment and includes a component geared toward supporting civil society organizations contributing to the goals of REDD+. www.un-redd.org/; www. norad.no/en/front/funding/climate-and-forest-initiative-support-scheme/.

\section{REFERENCES}

Andrade, Tonio (2016). The Gunpowder Age: China, Military Innovation, and the Rise of the West in World History. Princeton University Press.

Bello, David (2015). Across Mountain, Steppe, and Forest: Environment, Identity, and Empire in Qing China's Borderlands. Cambridge University Press.

Bogart, Dan (2005). "Turnpike Trusts and the Transportation Revolution in 18th Century England." Explorations in Economic History 42:479-508.

- - (2011). "Did the Glorious Revolution Contribute to the Transport Revolution? Evidence from Investment in Roads and Rivers." Economic History Review 64 (4): 1073-1112.

Bonney, Richard (1999). "Introduction." In The Rise of the Fiscal State in Europe, c. 12001815, edited by Richard Bonney. Oxford University Press.

Brewer, John (1989). The Sinews of Power: War, Money, and the English State, 1688-1783. Alfred A. Knopf.

Cardoso, José Luís, and Pedro Lains, eds. (2010). Paying for the Liberal State: The Rise of Public Finance in Nineteenth-Century Europe. Cambridge University Press.

Cashore, Benjamin, and Michael Howlett (2007). "Punctuating Which Equilibrium? Understanding Thermostatic Policy Dynamics in Pacific Northwest Forestry." American Journal of Political Science 51 (3): 532-551.

Daunton, Martin (2010). "Creating Legitimacy: Administering Taxation in Britain, 18151914." In Paying for the Liberal State: The Rise of Public Finance in Nineteenth-Century Europe, edited by José Luís Cardoso and Pedro Lains, 27-56. Cambridge University Press.

De Vries, Piet (2013). “The Modern Public-Private Demarcation: History and Trends in PPP." In The Routledge Companion to Public-Private Partnerships, edited by Piet de Vries and Etienne B. Yehoue, 9-28. Routledge.

Edmonds, Eric (2002). "Government Initiated Community Resource Management and Local Resource Extraction from Nepal's Forests." Journal of Development Economics 68 (1): $89-115$. 
Harling, Philip, and Peter Mandler (1993). "From 'Fiscal-Military' State to Laissez-Faire State, 1760-1850." Journal of British Studies 32:44-70.

Hocquet, Jean-Claude (1995). "City-State and Market Economy." In Economic Systems and State Finance, edited by Richard Bonney, 81-100. Clarendon.

Innes, Joanna (2009). Inferior Politics: Social Policies and Social Problems in EighteenthCentury Britain. Oxford University Press.

Janssens, Paul (2012). "Taxation in the Habsburg Low Countries and Belgium, 1579-1914." In The Rise of Fiscal States: A Global History, 1500-1914, edited by Bartolomé Yun-Casalilla and Patrick K. O’Brien, 67-92. Cambridge University Press.

Lieberman, Victor (2003, 2009). Strange Parallels Southeast Asia in Global Context, c.80o1830. 2 vols. Cambridge University Press.

Lindert, Peter (2004). Growing Public: Social Spending and Economic Growth since the Eighteenth Century. 2 vols. Cambridge University Press.

Menzies, Nicholas (1994). Forest and Land Management in Imperial China. Macmillan.

Miller, Ian (2015). Roots and Branches: Woodland Institutions in South China, 800-160o, $\mathrm{PhD}$ diss., Harvard University. Digital Access to Scholarship at Harvard.

O’Brien, Patrick K. (2012). "Afterword: Reflections on Fiscal Foundations and Contexts for the Formation of Economically Effective Eurasian States from the Rise of Venice to the Opium War." In The Rise of Fiscal States: A Global History, 1500-1914, edited by Bartolomé Yun-Casalilla and Patrick K. O'Brien, 442-453. Cambridge University Press.

Ormrod, W. M., and János Barta (1995), “The Feudal Structure and the Beginnings of State Finance." In Economic Systems and State Finance, edited by Richard Bonney, 53-79. Clarendon.

Pomeranz, Kenneth (1993). From Core to Hinterland: State, Society, and Economy in Inland North China, 1900-1937. University of California Press.

Rosenberg, Hans (1958). Bureaucracy, Aristocracy and Autocracy: The Prussian Experience, 1660-1815. Harvard University Press.

Scott, Anthony (2008). The Evolution of Resource Property Rights. Oxford University Press.

Sen, Amartya (1981). Poverty and Famines: An Essay on Entitlement and Deprivation. Oxford University Press.

Tilly, Charles, ed. (1975). The Formation of National States in Western Europe. Princeton University Press.

- - (1992). Capital, Coercion, and European States, AD 990-1992. Basil Blackwell.

Will, Pierre-Etienne, and R. Bin Wong, with James Lee and contributions by Jean Oi and Peter Perdue (1991). Nourish the People: The State Civilian Granary System in China, 1650-1850. University of Michigan Center for Chinese Studies.

Wong, R. Bin (1997). China Transformed: Historical Change and the Limits of European Experience. Cornell University Press.

Yamamoto, Koji (2018). Taming Capitalism before Its Triumph. Oxford University Press.

Yun-Casalilla, Bartolomé, and Patrick K. O'Brien, eds. (2012). The Rise of Fiscal States: A Global History, 1500-1914. Cambridge University Press.

Zhang, Meng (2017). Timber Trade along the Yangtze River: Market, Institutions, and Environment, 1750-1911. PhD diss., UCLA. 
